\title{
Lead Exposure: A Contributing Cause of the Current Breast Cancer Epidemic in Nigerian Women
}

\author{
Olusegun I. Alatise • Gerhard N. Schrauzer
}

Received: 18 November 2009 / Accepted: 4 January 2010 /

Published online: 3 March 2010

(C) The Author(s) 2010. This article is published with open access at Springerlink.com

\begin{abstract}
Breast cancer incidence in Nigerian women has significantly increased during the past three decades in parallel with the rapid industrialization of that country. This suggested that the associated widespread contamination of the soil and of the water supplies by lead $(\mathrm{Pb})$ and other industrial metals was a major contributing cause. Because of its many domestic, industrial, and automotive uses, $\mathrm{Pb}$ is of particular concern as it has been shown to promote the development of mammary tumors in murine mammary tumor virus-infected female $\mathrm{C} 3 \mathrm{H}$ mice at levels as low of $0.5 \mathrm{ppm} \mathrm{Pb}$ in the drinking water. Lead belongs to the group of selenium-antagonistic elements that interact with selenium (Se), abolishing its anti-carcinogenic effect. Lead on chronic, low-level exposure in addition also accelerates tumor growth rates. Higher levels of $\mathrm{Pb}$ were found in blood and head hair samples of newly diagnosed patients with breast cancer, all with infiltrating ductal carcinoma, the most common form of breast cancer in Nigeria, seen at Obafemi Awolowo University, than in cancer-free controls from the same area. Evidence for interactions between $\mathrm{Pb}$ and $\mathrm{Se}$ was obtained from blood, hair, and tumor biopsy tissue analyses. Furthermore, the $\mathrm{Pb}$ levels in hair samples of the patients were directly correlated with the volumes of their tumors, in accord with the tumor growth-promoting effects of $\mathrm{Pb}$. Conversely, Se levels in hair and blood were inversely correlated with the tumor volumes, consistent with the antiproliferative effects of Se. Several other elements, e.g., $\mathrm{Cd}, \mathrm{Hg}, \mathrm{Cr}, \mathrm{Sn}$, and $\mathrm{As}$, were detected in the scalp hair of the patients and the controls, although at significantly lower levels than those of $\mathrm{Pb}$. However, correlation calculations revealed them also to interact with Se, suggesting that only a fraction of the Se in organs and tissues is actually present in bioactive forms. In metal-exposed subjects, a state of latent Se deficiency may exist, resulting in depressed immune functions and increased cancer susceptibility. Evidence is presented to show that $\mathrm{Pb}$ and other metals also interact with iodine, another vitally
\end{abstract}

O. I. Alatise

Department of Anatomy and Cell Biology, College of Health Sciences, Obafemi Awolowo University, Ile-Ife, Nigeria

e-mail: segunalatishe@yahoo.co.uk

G. N. Schrauzer $(\bowtie)$

Department of Chemistry and Biochemistry, University of California, San Diego, CA, USA

e-mail: gschrauzer@ucsd.edu 
important essential trace element believed to protect against breast cancer development. Public health programs aiming at lowering the breast cancer risk of Nigerian women thus will have to include effective measures to protect the population from exposures to $\mathrm{Pb}$ and other industrial metals that are presently contaminating the environment and the water supplies.

Keywords Breast cancer $\cdot$ Lead $\cdot$ Cadmium $\cdot$ Tin $\cdot$ Chromium $\cdot$ Arsenic $\cdot$ Selenium $\cdot$ Iodine $\cdot$ Nigeria $\cdot$ Metal pollution

\section{Introduction}

Breast cancer ranks first among cancers occurring in women and second only to lung cancer as a cause of death in women worldwide [1]. Whereas breast cancer incidence is higher in the developed countries than in the developing countries, its incidence in the latter is increasing. In Nigeria, in particular, the incidence increased from 13.8-15.3/100,000 women in 1976 to 33.6/100,000 in 1992 and reached 116/100,000 in 2001, and is now the leading cause of cancer deaths among Nigerian women [2]. The causes of this alarming trend are not known. As changes of demographic profile, the acquisition of Western lifestyles, obesity, and altered socioeconomic status alone cannot explain this development, we hypothesized that the contamination of the soil and the water supplies by toxic metals during the period of industrialization could be a major contributing cause. Elements of interest within this context are lead $(\mathrm{Pb})$, chromium $(\mathrm{Cr})$, cadmium $(\mathrm{Cd})$, zinc $(\mathrm{Zn})$, tin $(\mathrm{Sn})$, and arsenic (As). However, the degree to which these elements might increase breast cancer risk depends yet on another element, selenium (Se), a nutritionally essential trace element whose anticarcinogenic properties have been demonstrated in numerous animal tumor model systems, and there is evidence that cancer mortalities in different countries are inversely associated with the dietary intakes of this element [3]. However, Se also interacts with other elements, mostly toxic heavy metals, in vivo. These interactions are part of natural metal detoxification processes, but result in the metabolic inactivation of Se and at sufficiently high exposure levels may over time produce a state akin to Se deficiency. In studies with female $\mathrm{C} 3 \mathrm{H}$ mice carrying the murine mammary tumor virus (MMTV), $\mathrm{Pb}$ at subtoxic levels was shown to abolish the cancer-protecting effect of Se at chronic exposure levels as low as $0.5 \mathrm{ppm}$ in the drinking water [4]. In Nigeria, the dietary Se intakes of the population are generally adequate [5], but $\mathrm{Pb}$ is an element of major concern as its many industrial and domestic uses, the presence of tetraethyl lead in gasoline, and the largely uncontrolled dumping of $\mathrm{Pb}$-containing residues have severely contaminated the soil and the water supplies in many parts of the country [6, 7]. Accordingly, a large segment of the population of Nigeria is chronically $\mathrm{Pb}$-exposed, including children. In one study of 218 children aged 6-35 months, 70\% had blood lead levels in excess of $10 \mu \mathrm{g} / \mathrm{dL}$ [8]. In adults, occupationally $\mathrm{Pb}$-exposed auto-mechanics exhibited mean blood and hair $\mathrm{Pb}$ levels of $48.50 \pm 9.08 \mu \mathrm{g} / \mathrm{dL}$ and $17.75 \pm 5.16 \mu \mathrm{g} / \mathrm{g}$, respectively [9], but $\mathrm{Pb}$ levels of unexposed controls from the same city (Abeokuta, in SW Nigeria) were elevated, with $33.65 \pm 10.09 \mu \mathrm{g}$ $\mathrm{Pb}$ per deciliter in blood and $14.30 \pm 5.90 \mu \mathrm{g} \mathrm{Pb}$ per gram in hair. Evidently, $\mathrm{Pb}$ pollution is so widespread that unexposed controls are difficult to find. The dangers of chronic $\mathrm{Pb}$ exposure are well recognized. Thus, a 1998 study found the immune status of occupationally $\mathrm{Pb}$-exposed Nigerian workers to be decreased, and its author pointed out that this may increase their susceptibility to infectious diseases, inflammatory disorders, and cancer [10]. However, since other metals may have similar effects and increase breast 
cancer risk, we decided to perform multi-element analyses of whole blood and scalp hair from breast cancer patients and from cancer-free controls, all from Ile-Ife, Osun State, Nigeria. In addition, element analyses were also obtained from breast biopsy samples of these patients. While our study was in progress, a report on trace element levels in the plasma and sera of Nigerian women from the Ibadan area with and without breast cancer was published [11]. These authors found lower $\mathrm{Cu}, \mathrm{Zn}$, and manganese (Mn) levels in the patient sera, but $\mathrm{Pb}$ and a number of other elements were not significantly elevated compared to their controls. Osun, Ondo, and other nearby states are in a region where almost $100 \%$ of the surface water-bearing wells have recently been reported to contain $\mathrm{Pb}$, $\mathrm{Ni}$, and $\mathrm{Cr}$ at levels exceeding the WHO and Nigeria Federal Ministry of Environment guidelines [12]. Furthermore, as plasma or serum contain these elements in significantly lower amounts, we determined them in whole blood, and since blood reflects only the most recent exposures, hair samples of the cases and controls were analyzed as well to obtain a record of the element exposures during the past several months. A total of 34 elements were analyzed in hair, which included iodine (I), a nonmetallic essential element believed to have protective functions against breast cancer development [13-15].

\section{Materials and Methods}

\section{Participants}

Twelve newly diagnosed breast cancer patients were recruited from the Surgery Clinics of the Obafemi Awolowo University Teaching Hospital Complex, Ile-Ife, Osun State, Nigeria.

Anthropometric data of the patients were measured and recorded. Also obtained was information on the current drug treatment. The hair treatment agents were recorded for all the patients and controls. Independent tests revealed none of the agents to contain lead. Table 1 lists socio-demographic data as obtained from completed questionnaires: type of tumor, tumor stage, histological characteristic of the tumors, and the body mass indexes (BMIs) as calculated from the heights and weights of the patients using the formula: BMI $\left(\mathrm{kg} / \mathrm{m}^{2}\right)=$ Weight $(\mathrm{kg}) /$ Height $^{2}\left(\mathrm{~m}^{2}\right)$.

The control subjects consisted of 12 aged-matched apparently healthy women, mostly members of the staff and students of the Obafemi Awolowo University Teaching Hospital Complex, Ile-Ife, Nigeria. To ensure uniformity, all patients and controls chosen were from the same ethnic background (Yoruba) and living in the southwestern part of Nigeria, as determined from their responses to questionnaires and clinical investigations. Excluded were pregnant or lactating women, women on hormonal therapy, women with inflammatory conditions, women on regular hematinics or taking supplements containing selenium, and women with diabetes mellitus, hypertension, hepatitis, tuberculosis, and jaundice.

\section{Blood, Tumor Tissue, and Hair Samples}

Samples of fasting blood of the patients and the controls were collected and were stored in tubes. Samples of scalp hair from the patients and the controls were taken using Teflon scissors and placed into polyethylene bags provided by the laboratory performing the determinations. Breast biopsy samples of the same patients were collected and prepared for trace element analysis using formalin as a preservative. The analyses of all samples, including the formalin solution, were performed by state-of-the-art inductively coupled plasma mass spectrometry methods [16]. 
Table 1 Patient Data

\begin{tabular}{lcclcccccc}
\hline No. & Age & $\begin{array}{l}\text { Age at } \\
\text { menarche }\end{array}$ & $\begin{array}{l}\text { Marital } \\
\text { status/parity }\end{array}$ & SES & BMI & $\begin{array}{l}\text { Tumor } \\
\text { size }(\mathrm{cm})\end{array}$ & TNM/His ${ }^{\mathrm{a}}$ & $\begin{array}{l}\text { Stage } \\
\text { Nottingham } \\
\text { score }\end{array}$ \\
\hline 1 & 80 & 20 & $\mathrm{M} / 8$ & 2 & 18.8 & $6 \times 5 \times 2$ & T3N1M0/IDC & 2 & 3 \\
2 & 68 & 16 & $\mathrm{M} / 8$ & 1 & 23.6 & $7 \times 4 \times 3$ & T4N1M0/IDC & 3 & $3^{3}$ \\
3 & 49 & 13 & $\mathrm{M} / 4$ & 2 & 28.3 & $5 \times 3 \times 2$ & T2N1M0/IDC & 2 & 2 \\
4 & 40 & 15 & $\mathrm{M} / 5$ & 1 & 25.6 & $12 \times 8 \times 5$ & T4N2M1/IDC & 4 & $3^{3}$ \\
5 & 58 & 15 & $\mathrm{M} / 0$ & 1 & 25.0 & $10 \times 8 \times 6$ & T4N2M0/IDC & 3 & 3 \\
6 & 60 & 19 & $\mathrm{M} / 7$ & 2 & 24.6 & $4 \times 3 \times 3$ & T2N1M0/IDC & 1 & 3 \\
7 & 51 & 20 & $\mathrm{M} / 3$ & 2 & 28.7 & $8 \times 5 \times 4$ & T3N1M0/IDC & 2 & 3 \\
8 & 40 & 20 & $\mathrm{M} / 4$ & 2 & 34.8 & $10 \times 8 \times 8$ & T4N2M0/IDC & 3 & 3 \\
9 & 62 & 16 & $\mathrm{M} / 5$ & 3 & 29.1 & $12 \times 10 \times 10$ & T4N1M0/IDC & 3 & 3 \\
10 & 40 & 16 & $\mathrm{M} / 0$ & 1 & 25.3 & $6 \times 4 \times 3$ & T3N0M0/IDC & 2 & 3 \\
11 & 44 & 14 & $\mathrm{M} / 4$ & 1 & 34.8 & $10 \times 8 \times 6$ & T4N2M0/IDC & 3 & $3^{\mathrm{b}}$ \\
12 & 45 & 15 & $\mathrm{M} / 5$ & 1 & 25.5 & $12 \times 8 \times 8$ & T4N1M1/IDC & 4 & $3^{\mathrm{b}}$ \\
\hline
\end{tabular}

IDC infiltrating ductal carcinoma

${ }^{\text {a }}$ SES socio-economic status: 1 = low, 2 = medium, 3 = high

${ }^{\mathrm{b}}$ Expired

\section{Results}

The histologically confirmed type of breast cancer of all patients of the present study was invasive ductal carcinoma (IDC), the most common form of breast cancer in Nigeria. The tumors of all patients were locally advanced, as assessed in terms of their TNM stage and their Nottingham's scores. The ages of the patients, their ages at menarche, marital status, parity, socioeconomic status, BMI, tumor size, tumor stage, number of nodes and histology (TNM/His), disease stage, and their Nottingham scores are given in Table 1. The ages ranged from 40 to 80 years, and the median was 50 years. Their median BMI was 25.6 and their median age at menarche 16.0 years. Most of the patients were multigravida and on average breastfed each child for over 1 year. Socioeconomic status (SES) of the patients was assessed on annual income and was numerically expressed as 1 for the low, 2 for the medium, and 3 for the high-income categories. The SES of six patients was low, of five patients medium, and of one high. While this study was in progress, four patients expired. Death of these patients was associated with low SES $(P<0.02)$, high tumor stage $(P<0.01)$, and large tumor volume $(P=0.05)$, but not with age $(P=0.32)$ and the BMI $(P=0.78)$.

\section{Elements in Whole Blood and Hair Samples}

Average concentrations and ranges of elements determined in whole blood and in hair of the patients and controls, with calculated Student's $t$ test $P$ values and laboratory reference ranges are given in Tables 2 and 3. Table 4 lists elements determined in the breast tumor biopsy samples by us and by other authors. Although the samples were analyzed for a total of 20 elements, the results for only 11 elements are given since the remaining nine elements, i.e., $\mathrm{Sb}, \mathrm{Be}, \mathrm{Bi}, \mathrm{Pt}, \mathrm{Tl}, \mathrm{Th}, \mathrm{U}, \mathrm{Hg}$, and $\mathrm{W}$, were either present in amounts below the detection limit or absent. Based on the results in Table 4, the tumors of our patients contained comparable amounts of $\mathrm{Zn}, \mathrm{Cu}, \mathrm{Fe}$, and $\mathrm{Ni}$ and more $\mathrm{Cr}, \mathrm{As}$, and $\mathrm{Se}$ than that reported by Risk and Sky-Peck [17]. Our mean amount of $\mathrm{Pb}$ was lower but essentially the 
Table 2 Blood Analysis Results

\begin{tabular}{|c|c|c|c|c|c|c|}
\hline \multirow[t]{2}{*}{ Elements and units } & \multicolumn{2}{|l|}{ Control } & \multicolumn{2}{|l|}{ Cases } & \multirow[t]{2}{*}{$P$ value $^{\mathrm{a}}$} & \multirow[t]{2}{*}{ Reference range } \\
\hline & Mean & Range & Mean & Range & & \\
\hline $\mathrm{Cu}(\mu \mathrm{g} / \mathrm{dL})$ & 98.9 & $76-145$ & 132.5 & $105-157$ & $<0.001$ & $61-122$ \\
\hline $\mathrm{Zn}(\mu \mathrm{g} / \mathrm{dL})$ & 617 & $410-760$ & 627.6 & $491-777$ & 0.15 & $420-810$ \\
\hline $\mathrm{Pb}(\mu \mathrm{g} / \mathrm{dL})$ & 5.0 & $1.8-8.5$ & 6.1 & $2.2-14.0$ & $<0.01$ & $<3.5$ \\
\hline $\mathrm{Se}(\mu \mathrm{g} / \mathrm{L})$ & 303 & $150-462$ & 291 & $181-601$ & 0.79 & $130-340$ \\
\hline $\mathrm{Cd}(\mu \mathrm{g} / \mathrm{L})$ & 1.7 & $1.4-2.1$ & 1.5 & $0.4-1.9$ & 0.85 & $<4.0$ \\
\hline $\mathrm{Hg}(\mu \mathrm{g} / \mathrm{L})$ & 1.9 & $0.6-3.6$ & 2.4 & $0.9-5.2$ & 0.11 & $<5.0$ \\
\hline As $(\mu \mathrm{g} / \mathrm{L})$ & 6.8 & $4.0-12$ & 7.6 & $3.4-16$ & 0.11 & $<20$ \\
\hline $\operatorname{Mn}(\mu \mathrm{g} / \mathrm{L})$ & 10.4 & $6-19$ & 9.1 & $6.0-15$ & 0.56 & $6-19$ \\
\hline $\mathrm{Sr}(\mu \mathrm{g} / \mathrm{L})$ & 34.5 & $3.8-67$ & 33.7 & $19-64$ & 0.10 & $8-38$ \\
\hline $\mathrm{Ca}(\mathrm{mg} / \mathrm{dL})$ & 5.8 & $5.3-5.6$ & 5.9 & $5.5-6.4$ & 0.31 & $4.4-6.9$ \\
\hline $\mathrm{Mg}(\mathrm{mg} / \mathrm{dL})$ & 3.4 & $2.9-4.2$ & 3.6 & $2.9-4.2$ & 0.65 & $2.8-4.4$ \\
\hline $\mathrm{Li}(\mu \mathrm{g} / \mathrm{L})$ & 0.76 & $0.5-1.7$ & 0.95 & $0.4-1.8$ & $<0.01$ & $0.3-20$ \\
\hline Co $(\mu \mathrm{g} / \mathrm{L})$ & 0.53 & $0.2-0.9$ & 0.42 & $0.2-1.1$ & 0.91 & $<4.0$ \\
\hline $\mathrm{Zn} / \mathrm{Cu}$ & 7.6 & $5.4-8.6$ & 5.2 & $3.2-7.6$ & 0.004 & $-\mathrm{b}$ \\
\hline $\mathrm{Ca} / \mathrm{Mg}$ & 1.70 & $1.5-2.1$ & 1.63 & $1.4-2.2$ & 0.60 & $-\mathrm{b}$ \\
\hline
\end{tabular}

a Student's $t$ test

${ }^{\mathrm{b}}$ Reference range not available

same as the median level reported by Ionescu et al. $[18,19]$. The median amounts of the elements measured by the latter authors were comparable or within range to ours, but their value for $\mathrm{Al}$ given in [18] was significantly lower.

\section{Discussion}

Associations with Demographic Parameters

Partitioning of the patients with respect to their SES revealed low SES associated with higher tumor stage $(P<0.0008)$ and with larger tumor volumes on admission $(P<0.03)$, suggesting that the women of low SES sought treatment later than women of the medium or high socioeconomic classes. This conclusion is supported by the fact that the four patients who expired while this work was in progress all belonged to the lowest socioeconomic class, were in advanced tumor stages, and had large tumors. Low SES also was associated with earlier menarche $(P<0.05)$, but not with parity $(P=0.38)$ or BMI $(P=0.89)$. Among trace elements, low SES was associated with low I levels in hair $(P=0.01)$, high $\mathrm{Cu}$ concentration in blood $(P=0.020)$, and low $\mathrm{Zn} / \mathrm{Cu}$ ratios in blood $(P=0.02)$, both reflecting more advanced disease.

Associations with Individual Elements

Lead According to Table 2, the means and the ranges of blood lead levels of the controls and cases were 5.0, 1.8-8.5 and 6.1, and 2.2-21 $\mu \mathrm{g} / \mathrm{dL}$, respectively. Both means are above the laboratory reference value for $\mathrm{Pb}$ of $3.5 \mu \mathrm{g} / \mathrm{dL}$ [15], and the difference of the means between cases and controls is statistically significant $(P<0.01)$. It should be noted that the 
Table 3 Elements in Scalp Hair of Cases and Controls (Unit: mcg/g)

\begin{tabular}{|c|c|c|c|c|c|c|}
\hline \multirow[t]{2}{*}{ Elements } & \multicolumn{2}{|l|}{ Control } & \multicolumn{2}{|l|}{ Cases } & \multirow[t]{2}{*}{$\mathrm{P}$ value ${ }^{\mathrm{a}}$} & \multirow[t]{2}{*}{ Reference range } \\
\hline & Mean & Range & Mean & Range & & \\
\hline $\mathrm{Pb}$ (all) & 251 & $0.76-2900$ & 497 & $5-5000$ & .75 & $<1$ \\
\hline $\mathrm{Pb}^{\mathrm{b}}$ & 10.3 & $0.76-26$ & 23.8 & $5-67$ & .19 & $<1$ \\
\hline $\mathrm{Cd}$ & 0.32 & $0.004-0.87$ & 0.45 & $0.03-3.6$ & .009 & $<.10$ \\
\hline $\mathrm{Hg}$ & 0.40 & $0.02-1.2$ & 0.67 & $0.06-2.74$ & .53 & $<1.1$ \\
\hline As & 0.09 & $0.02-0.18$ & 0.08 & $0.004-0.18$ & .28 & $<.30$ \\
\hline $\mathrm{Cu}$ & 40.1 & $9.7-110$ & 48.41 & $9.6-110$ & .05 & $12-35$ \\
\hline $\mathrm{Zn}$ & 617 & $410-760$ & 627 & $491-777$ & .15 & $140-220$ \\
\hline $\mathrm{Se}$ & 0.886 & $0.48-1.34$ & 0.727 & $0.51-1.1$ & .04 & $.95-1.7$ \\
\hline $\mathrm{Mn}$ & 23.7 & $1-170$ & 15.8 & $4.8-36$ & .08 & $.15-.65$ \\
\hline $\mathrm{Sr}$ & 9.4 & $1.7-27$ & 7.7 & $2.3-25$ & .03 & $.5-7.6$ \\
\hline $\mathrm{Ca}$ & 2530 & $369-865$ & 1617 & $360-5570$ & .01 & $300-1200$ \\
\hline $\mathrm{Mg}$ & 477 & $57-2600$ & 227 & $55-990$ & .31 & $35-120$ \\
\hline $\mathrm{Li}$ & 0.053 & $.4-1.7$ & 0.046 & $0.5-1.8$ & .09 & $.007-.023$ \\
\hline $\mathrm{Co}$ & 1.74 & $0.03-15.5$ & 0.93 & $0.13-4.5$ & $<.01$ & $.013-.050$ \\
\hline I & 1.85 & $0.32-5.9$ & 1.27 & $0.2-3.32$ & .96 & $.25-1.3$ \\
\hline $\mathrm{S}$ & 35336 & $(2-4.5) \times 10^{4}$ & 36437 & $(2-4.5) \times 10^{4}$ & .57 & $(4.4-5.2) \times 10^{4}$ \\
\hline $\mathrm{P}$ & 166 & $91-199$ & 149 & $90-202$ & .56 & $160-250$ \\
\hline $\mathrm{Ag}$ & 0.10 & $0.01-0.32$ & 0.067 & $0.01-0.32$ & .096 & $<.15$ \\
\hline $\mathrm{Fe}$ & 96.9 & $31-300$ & 148 & $30-347$ & .17 & $5.4-14$ \\
\hline $\mathrm{Cr}$ & 1.10 & $0.62-2.1$ & 0.96 & $0.45-1.45$ & .36 & $.20-.40$ \\
\hline V & 0.27 & $0.082-0.78$ & 0.35 & $0.078-0.78$ & .98 & $.018-.065$ \\
\hline Mo & 0.12 & $0.01-0.46$ & 0.23 & $0.026-1.0$ & .81 & $.028-.056$ \\
\hline $\mathrm{B}$ & 4.55 & $0.84-19$ & 3.35 & $1.0-11$ & .48 & $.30-2.0$ \\
\hline $\mathrm{Na}$ & 852 & $24-4200$ & 510 & $19-4200$ & .005 & $12-90$ \\
\hline $\mathrm{K}$ & 417 & $12-1100$ & 393 & $25-970$ & .19 & $8-38$ \\
\hline $\mathrm{Ba}$ & 18.6 & $1.4-130$ & 14.2 & $4.2-41$ & .86 & $.26-3.0$ \\
\hline $\mathrm{Be}$ & 0.026 & $0.001-0.25$ & 1.94 & $0.01-25$ & .93 & $<0.020$ \\
\hline $\mathrm{Bi}$ & 0.49 & $0.017-3.8$ & 0.23 & $0.02-1.7$ & .38 & $<2.0$ \\
\hline $\mathrm{Ni}$ & 1.98 & $0.08-7$ & 1.91 & $0.2-7.8$ & .09 & $<0.40$ \\
\hline $\mathrm{Tl}$ & 0.49 & $0.001-3.2$ & 0.01 & $0.003-0.06$ & .42 & $<0.010$ \\
\hline $\mathrm{Th}$ & 0.010 & $0.003-0.026$ & 0.019 & $0.003-0.057$ & .26 & $<0.005$ \\
\hline $\mathrm{U}$ & 0.029 & $0.003-0.072$ & 0.53 & $0.017-0.15$ & .15 & $<0.060$ \\
\hline $\mathrm{Ti}$ & 1.74 & $3.7-21$ & 2.4 & $0.52-5.9$ & .31 & $<1.0$ \\
\hline $\mathrm{Sn}$ & 15.3 & $0.1-120$ & 0.2 & $0.38-120$ & .46 & $<0.30$ \\
\hline $\mathrm{Al}$ & 39.6 & $10-90$ & 69.7 & $13-150$ & .06 & $<7.0$ \\
\hline $\mathrm{Zn} / \mathrm{Cu}$ & 8.21 & $1.2-16.3$ & 4.58 & $1.0-8.1$ & .34 & $4-20$ \\
\hline $\mathrm{Ca} / \mathrm{Mg}$ & 8.35 & $1.95-17.4$ & 8.91 & $3.3-16.8$ & .28 & $4-30$ \\
\hline $\mathrm{Ca} / \mathrm{P}$ & 17.3 & $2.1-95$ & 8.91 & $2.5-35$ & .001 & $1-12$ \\
\hline $\mathrm{Na} / \mathrm{K}$ & 1.46 & $0.41-4.33$ & 1.04 & $0.32-4.33$ & $<.001$ & $0.5-10$ \\
\hline $\mathrm{Zn} / \mathrm{Cd}$ & 688 & 296-999 & 653 & 564-999 & .13 & $>800$ \\
\hline
\end{tabular}

\footnotetext{
${ }^{\mathrm{a}}$ Student t-test. ${ }^{\mathrm{b}}$ High $\mathrm{Pb}$ outliers $(1200-5000 \mathrm{mcg} \mathrm{Pb} / \mathrm{g})$ omitted
} 
Table 4 Elements in Breast Tumor Tissue Samples (mcg/g dry wt.)

\begin{tabular}{|c|c|c|c|c|c|}
\hline & \multicolumn{2}{|c|}{ This work } & \multirow{2}{*}{$\begin{array}{l}\text { Rizk and Sky-Peck [17] } \\
\text { Median }\end{array}$} & \multicolumn{2}{|c|}{ Ionescu et al. $[18,19]$} \\
\hline & Median & Range & & Median & \\
\hline $\mathrm{Pb}$ & 0.11 & $0.022-0.21$ & $1.55 \pm 1.24$ & 0.10 & $0.009-0.98$ \\
\hline $\mathrm{Cr}$ & 0.91 & $0.55-1.28$ & $0.49 \pm 0.80$ & 0.82 & $0.31-5.98$ \\
\hline $\mathrm{Cd}$ & 0.14 & $0.05-0.36$ & ND & 0.042 & $0.009-0.55$ \\
\hline As & 0.077 & $0.032-0.11$ & $0.13 \pm 0.09$ & $0.03^{\mathrm{a}}$ & \\
\hline $\mathrm{Zn}$ & 22.8 & $5.95-54.9$ & $68.1 \pm 26.0$ & 17.1 & $1.3-97.9$ \\
\hline $\mathrm{Cu}$ & 2.79 & $1.0-5.95$ & $21.0 \pm 10.7$ & 0.92 & $9.32-44.7$ \\
\hline $\mathrm{Se}$ & 0.96 & $0.19-1.60$ & $1.02 \pm 0.43$ & ND & \\
\hline $\mathrm{Fe}$ & 91.1 & $19.6-196$ & $238.5 \pm 113.0$ & 53.2 & $14.7-205.9$ \\
\hline $\mathrm{Al}$ & 2.11 & $0.59-4.35$ & ND & $0.17^{\mathrm{a}}$ & \\
\hline $\mathrm{Ni}$ & 0.100 & $0.014-0.32$ & $1.27 \pm 0.59$ & 0.99 & $0.407-3.36$ \\
\hline $\mathrm{Sn}$ & 0.022 & $0.014-0.060$ & ND & $0.044^{\mathrm{a}}$ & \\
\hline
\end{tabular}

ND not determined

${ }^{\text {a }}$ Range not given

patient with the highest blood $\mathrm{Pb}$ level, $14 \mu \mathrm{g} / \mathrm{dL}$ (no. 12 in Table 1), was with stage 4 breast cancer and spinal metastases, the most seriously ill, and has since died of her disease.

$\mathrm{Pb}$ in blood was directly correlated with $\mathrm{Pb}$ in tumors $(P=0.05)$, directly with $\mathrm{Se}$ in blood $(P=0.02)$, and inversely correlated with hair $\mathrm{Se}(P=0.04)$. $\mathrm{Pb}$ in tumors, on the other hand, was inversely associated with blood Se $(P=0.04)$. These results indicate that $\mathrm{Pb}$ interacts with Se in vivo.

The mean $\mathrm{Pb}$ in hair, after elimination of the high outliers with levels of $1,200-5,000 \mu \mathrm{g}$ $\mathrm{Pb}$ per gram, was $23.6 \mu \mathrm{g} / \mathrm{g}$, more than twice higher in the cases than the $10.3 \mu \mathrm{g} / \mathrm{g}$ of the controls (see Table 3). Associations of hair $\mathrm{Pb}$ levels of the cases were significantly direct with the BMI $(P=0.0455)$, as well with the logs of the tumor volumes $(P=0.0482)$, and inverse with the hair $\mathrm{Zn}(P=0.0174)$ and blood Se values $(P=0.05)$.

On the other hand, hair $\mathrm{Pb}$ was directly correlated with hair iodine $(P=0.034)$, which is to be expected as $\mathrm{Pb}$ has a high affinity for iodine and there is evidence of interactions between the two elements in vivo.

Some of the same elements were previously reported by Nnorom et al. [20] from analyses of hair samples collected in three industrialized and non-industrialized towns in southeastern Nigeria. These authors found that $89 \%$ of their study subjects had hair $\mathrm{Pb}$ levels $>30 \mu \mathrm{g} / \mathrm{g}, 20 \%$ levels $>110 \mu \mathrm{g} / \mathrm{g}$. Of our patients, four $(33 \%)$ had $\mathrm{Pb}$ values $>30 \mu \mathrm{g} / \mathrm{g}$, among them one with $\mathrm{Pb}$ levels reaching 1,200 $\mu \mathrm{g} / \mathrm{g}$ and another with 5,000 $\mu \mathrm{g} / \mathrm{g}$. Only one of our controls exhibited a similarly high $\mathrm{Pb}$ value, $2,900 \mu \mathrm{g} / \mathrm{g}$; the $\mathrm{Pb}$ levels of the remaining controls were $<30 \mu \mathrm{g} / \mathrm{g}$.

Selenium Blood Se was inversely correlated with the logarithms of the tumor volumes $(P=$ 0.03 ), suggesting that Se inhibits tumor growth.

Blood Se was directly correlated with Se in hair $(P=0.05)$; the association with $\mathrm{Se}$ in tumors was direct but statistically insignificant $(P=0.07)$. Hair Se was directly correlated with age $(P=0.0057)$ and with parity $(P=0.036)$ and inversely correlated with BMI $(P=$ 0.037). As to the interactions of Se with $\mathrm{Pb}$ in blood, tumors, and hair, see the section on 'lead' above. In addition, blood Se was inversely correlated with $\mathrm{Zn}$ in blood $(P=0.004)$, Sn 
in hair $(P=0.027)$, and Mo in hair $(P=0.032)$ and directly correlated with $\mathrm{Zn}$ in tumors $(P=$ 0.002). Direct associations of hair Se with hair As in patients and in controls were significantly direct, with $P<0.005$ and $P<0.02$, respectively. The associations of Se with $\mathrm{Pb}, \mathrm{Zn}, \mathrm{Cr}, \mathrm{Sn}$, and As are not unexpected as these elements are known to interact with $\mathrm{Se}$ and to possess Se-antagonistic properties. In experiments with female $\mathrm{C} 3 \mathrm{H}$ mice infected with the MMTV, the exposure of the animals to low levels of $\mathrm{Pb}, \mathrm{Zn}, \mathrm{Cr}$, and As in the supply water abolished the cancer-protecting effects of Se and stimulated tumor growth [4].

Cadmium $\mathrm{Cd}$ has also been shown to interact with Se in vivo and to abolish the cancerprotecting effects of Se in the MMTV-infected mice [21], and a statistically significant direct association between the estimated dietary $\mathrm{Cd}$ intake parameters and the breast cancer mortalities in different countries has been reported [22]. In our patients, blood Cd levels were inversely correlated with those of Se, but as blood Cd concentrations were low, this association was only of borderline statistical significance $(P=0.09)$. Similarly only of borderline statistical significance $(P=0.06)$ was the direct interaction of $\mathrm{Cd}$ in the tumors with Se levels in tumors. However, although the statistical significance of these associations was low, the evidence suggests that the two elements interact.

As $\mathrm{Cd}$ is also known to interact with $\mathrm{Zn}$, the inverse association of $\mathrm{Cd}$ in blood with $\mathrm{Zn}$ in the tumors with $P=0.0238$ is of interest as it suggests that $\mathrm{Cd}$ inhibits the transfer of $\mathrm{Zn}$ to the tumor. In the experiments with $\mathrm{C} 3 \mathrm{H}$ mice [21], slower tumor growth in the $\mathrm{Cd}$ exposed mice was attributed to the $\mathrm{Cd}$-induced $\mathrm{Zn}$ depletion of the tumors. An inverse correlation was also observed between $\mathrm{Cd}$ in hair and $\mathrm{Zn}$ in hair $(P=0.044)$. On the other hand, the hair $\mathrm{Cd}$ levels were directly correlated with BMI $(P=0.0017)$, suggesting that $\mathrm{Cd}$ has metabolic effects resulting in obesity.

Copper Table 2 reveals patients to have higher blood $\mathrm{Cu}$ levels $(P<0.001)$ and lower blood $\mathrm{Zn} / \mathrm{Cu}$ ratios $(P<0.04)$ than the controls. Table 3 shows that hair $\mathrm{Cu}$ levels of the patients were also significantly $(P=0.05)$ higher than those of the controls. The differences between these values reflect physiological responses to the disease process and/or its treatment, as evidenced by the direct correlation of the blood $\mathrm{Cu}$ concentrations with the clinically determined tumor stages of the patients $(P<0.05)$ and the tumor volumes on admission $(P<0.03)$. Cu in the tumors was directly correlated with tumor $\mathrm{Se}(P=0.002)$ and with tumor $\mathrm{Cd}$ and $\mathrm{Zn}(P=0.017$ and $<0.01$, respectively). In addition, $\mathrm{Cu}$ in hair was directly correlated with $\mathrm{Cd}$ in tumors $(P=0.017)$. Interactions between $\mathrm{Cd}$ and $\mathrm{Cu}$ are well known [23, 24].

Zinc $\mathrm{Zn}$ in the blood of the patients was inversely correlated with blood Se $(P=0.0042)$ and also with tumor $\mathrm{Cu}(P=0.04)$. The tumor $\mathrm{Zn}$ concentrations were directly correlated with those of $\mathrm{Se}$ in tumors $(P=0.0018)$, with $\mathrm{Cu}$ in tumors $(P<0.016), \mathrm{Cr}$ in tumors $(P<0.04)$, and with $\mathrm{Cd}$ in tumors $(P=0.007)$ and inversely correlated with $\mathrm{Cd}$ in blood $(P=0.027)$. The hair $\mathrm{Zn}$ concentrations of the patients were inversely correlated with the $\mathrm{Pb}$ hair $(P=$ $0.0174)$, the Mo hair $(P=0.0046)$, and $\mathrm{Cd}$ hair concentrations $(P=0.044)$. The blood and hair $\mathrm{Zn} / \mathrm{Cu}$ ratios were lower than normal in patients than in the controls (see Tables 2 and 3). This is often the case in cancer patients, but is also seen in patients with inflammatory conditions. The blood $\mathrm{Zn} / \mathrm{Cu}$ ratios were also significantly correlated with SES $(P=0.02)$ and inversely correlated with the tumor volume $(P=0.032)$ and the tumor stage they were in $(P=0.020)$, in accord with their more advanced stage of disease on admission. The blood $\mathrm{Zn} / \mathrm{Cu}$ ratios were also directly associated with the hair $\mathrm{Na} / \mathrm{K}$ ratios $(P=0.04)$. As these reflect the ratio between intracellular and extracellular potassium and 
are controlled by the $\mathrm{Na} / \mathrm{K}$-ATPase activity, they are often lower in cancer patients, but this is also seen in other diseases. The hair $\mathrm{Zn} / \mathrm{Cu}$ ratios showed no significant associations with $\mathrm{SES}$, tumor stage, or the tumor volumes, presumably because the hair $\mathrm{Zn} / \mathrm{Cu}$ ratios reflect the average value over 3-4 months prior to hair sample collection.

Iodine Hair I was inversely correlated with tumor stage $(P=0.03)$ and tumor volume $(P=$ $0.01)$, directly correlated with $\mathrm{Cu}$ in blood $(P=0.05), \mathrm{Cu}$ in hair $(P=0.004), \mathrm{Ni}$ in hair $(P<$ $0.01), \mathrm{Pb}$ in hair $(P=0.015)$, Mo in hair $(P=0.015)$, and As in tumor $(P=0.05)$ and inversely with $\mathrm{Zn}$ in blood $(P=0.006)$. These findings are suggestive of an anti-breast cancer effect of iodine $[13-15,25]$. However, the present study suggests that the biological effects of iodine are counteracted by a variety of metallic elements.

\section{Other Elements}

Tin (Sn) Several of the study subjects exhibited greatly elevated hair $\mathrm{Sn}$ levels in patients more than the controls ( $P=0.002$, see Table 3$)$. Exposures to $\mathrm{Sn}$ are possible as Nigeria is a major producer of this element. We are led to conclude that excessive exposures to tin should be viewed as harmful and should be avoided. In our Sn-exposed patients, hair $\mathrm{Sn}$ values were directly correlated with tumor volumes $(P=0.04)$ and inversely correlated with the levels of Se in tumors, consistent with the Se-antagonistic properties of $\mathrm{Sn}[26]$.

Molybdenum In hair, Mo was associated inversely with $\mathrm{Cr}$ in tumor $(P=0.01)$ and $\mathrm{Se}$ in tumor $(P=0.02)$ and directly with $\mathrm{Pb}$ in hair $(P=0.006)$. These associations suggest a role of Mo in breast cancer, and there is at least one paper which indicates that Mo inhibits $N$-nitroso- $N$-methylurea-induced mammary carcinogenesis in rats [27].

Chromium In hair, $\mathrm{Cr}$ was directly correlated with $\mathrm{Fe}$ in hair $(P=0.0035), \mathrm{Fe}$ in tumor $(P=0.004), \mathrm{Pb}$ in tumor $(P=0.03), \mathrm{Pb}$ in hair $(P=0.07)$ and with As in tumor $(P=0.003)$. Coyle et al. [28] showed with univariate analysis that chromium was positively associated with the breast cancer rates in Texas, between 1995 and 2000. As early as in 1977 [22], comparisons of the age-corrected breast cancer mortalities in different countries with the estimated dietary $\mathrm{Cr}$ intakes produced statistically significant direct associations suggesting that $\mathrm{Cr}$ promotes breast cancer development. More recent studies established that dietary $\mathrm{Cr}$ acts as a Se-antagonist, abolishes the anticarcinogenic effects of Se, and promotes tumor growth in MMTV-infected female $\mathrm{C} 3 \mathrm{H}$ mice [29]

Boron In hair, boron (B) was directly correlated with $\mathrm{Pb}$ in blood $(P=0.006)$, As in hair $(P=0.026)$, and with lithium $(\mathrm{Li})$ in hair $(P=0.02)$. Our study produced no statistically significant direct and possible beneficial effect or inverse association with Se in hair, blood, or tumors of our patients, but the observed direct association with $\mathrm{Pb}$ in blood could mean that it has an indirect effect on transport or tissue distribution of the element. Similarly, with seven of our patients, a statistically highly significant inverse association of the B levels in hair with the $\mathrm{Cd}$ concentrations in their tumors was obtained $\left(r^{2}=0.865, P=0.0024\right)$. Otherwise, little is still known about its role in breast cancer except that boric acid has been shown to inhibit cell growth in certain breast and prostate cancer cell lines [30].

Manganese In hair, Mn was significantly correlated with As in tumor $(P=0.032)$ and with $\mathrm{Pb}$ in hair $(P<0.04)$. Mn occurs in manganese superoxide dismutase (MnSOD) which exists 
in several genotypes of which some are believed to cause oxidative damage to DNA and increase breast cancer risk [31]. Epidemiologic studies on the MnSOD genotype may contribute to an increased risk of breast cancer in the presence of specific environmental exposures [32].

Lithium In hair, Li was inversely correlated with $\mathrm{Cd}$ in tumor $(P=0.005)$ and directly with $\mathrm{Cr}$ in hair $(P=0.02), \mathrm{Fe}$ in hair $(P=0.02)$, and As in tumor $(P<0.005)$. Lithium, which is used to treat bipolar psychiatric disorders, can stimulate proliferation of a number of cells in tissue culture. Proliferation of MCF-7 human breast cancer cells, which also respond to EGF and estrogens, was stimulated by $\mathrm{LiCl}(1-5 \mathrm{mM})$ within the concentration range that is encountered during human therapy with lithium. Stimulation of growth was specific for lithium; rubidium, potassium, and sodium showed no such effect [33]. Another study demonstrated that lithium has significant immunoregulatory effects by increasing the production of both pro-inflammatory cytokines (IFN $\gamma, \mathrm{TNF} \alpha$, and IL-8) and negative immunoregulatory cytokines or proteins (IL-10 and IL-1RA) [34]. In our subjects, the observed association of $\mathrm{Li}$ with other elements may be associated with its emerging role as a nutritionally essential element [35]. One of its effects at low nutritional levels is to affect the transport and organ distribution of other elements.

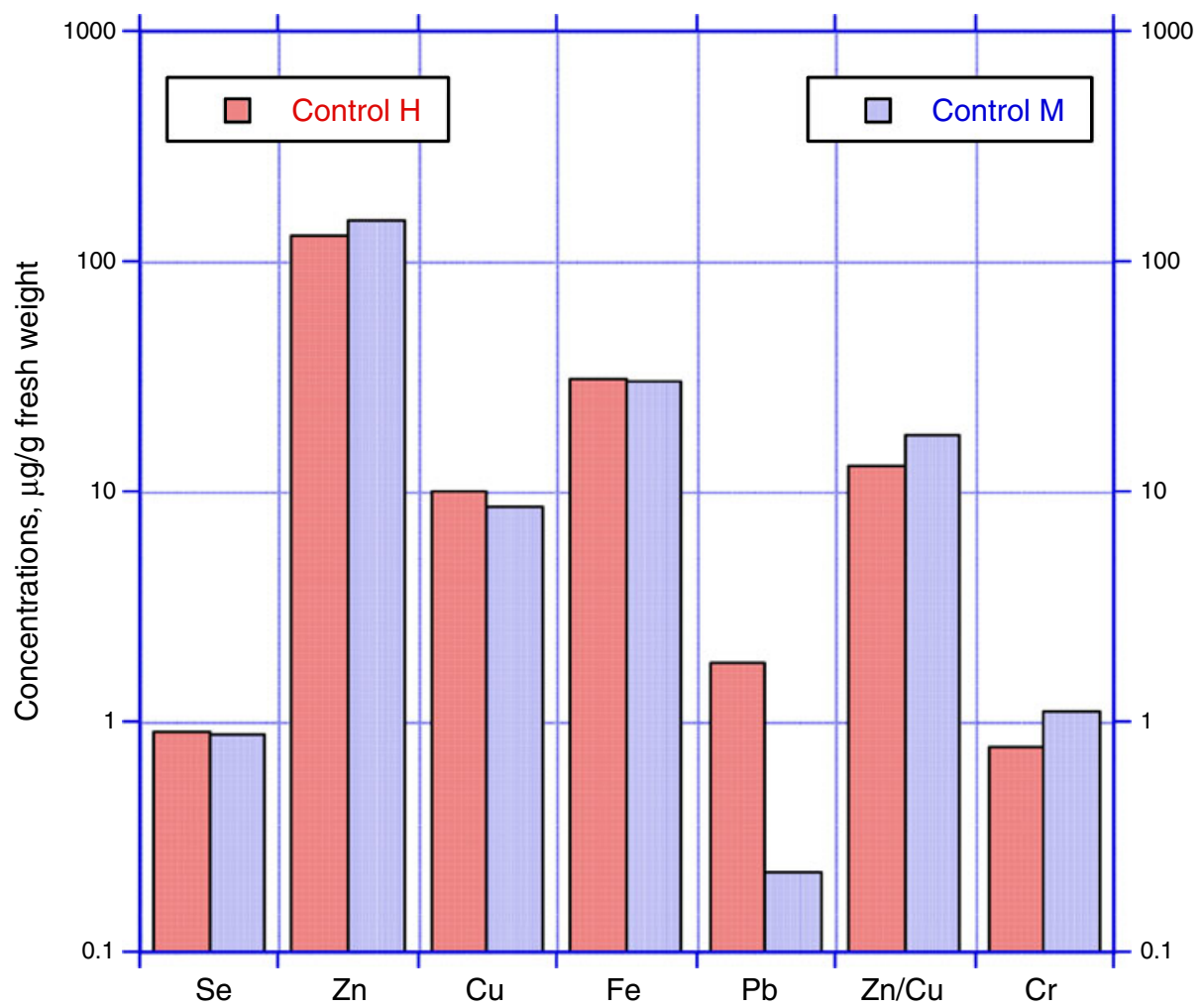

Fig. 1 Comparison of select element concentrations and the $\mathrm{Zn} / \mathrm{Cu}$ ratios in the hair of a Nigerian control subject ('Control H') with low-Pb exposure with those previously observed [4] in the hair of MMTV-infected female $\mathrm{C} 3 \mathrm{H}$ mouse ('Control M') 
Alkaline Earth Elements Brief mention is made that the levels of calcium and strontium in hair were lower in the cases than in the controls $(P<0.01$ and $P=0.03)$, but these differences also cannot be attributed to a specific cancer-related condition. The hair $\mathrm{Ca} / \mathrm{P}$ ratios of the patients were lower than that of the controls $(P=0.001)$, but were mostly within the reference range of 1-12 irrespective of tumor volume. The one patient with an unusually high $\mathrm{Ca} / \mathrm{P}$ ratio of 30.4 had stage 1 breast cancer and had recently undergone quadrantectomy followed by radiation and chemotherapy; the combined effects of these treatments may have been responsible for this anomalous result.

\section{Relevance of the Studies with Pb-Exposed MMTV-Infected Mice}

In the recently reported study [4] with female MMTV-infected $\mathrm{C} 3 \mathrm{H}$ mice, $\mathrm{Pb}$ at the level of just $0.50 \mathrm{ppm}$ in the drinking water was shown to abolish the anticarcinogenic effects of $0.65 \mathrm{ppm}$ of Se in the feed. As fragments of a human variant of MMTV have been detected in a significant percentage of human breast cancer tissues [36], the relevance of this tumor model system to human breast cancer is well established. Furthermore, since the exposure level of $\mathrm{Pb}$ chosen in that study was of the same order of magnitude as found in some human water supplies, comparisons of the results with the mice [4] with those of $\mathrm{Pb}$ exposed Nigerian women with and without breast cancer are permissible.

Figure 1 shows the observed levels of $\mathrm{Se}, \mathrm{Zn}, \mathrm{Cu}, \mathrm{Fe}, \mathrm{Pb}, \mathrm{Cr}$, and the $\mathrm{Zn} / \mathrm{Cu}$ ratio in the hair of lead-unexposed female $\mathrm{C} 3 \mathrm{H}$ mouse and of one of our "low-Pb" human controls of the present study. Figure 2 compares the same elements and the $\mathrm{Zn} / \mathrm{Cu}$ ratio in the hair of a



Fig. 2 Comparison of select element concentrations and the $\mathrm{Zn} / \mathrm{Cu}$ ratios in the hair of a Nigerian control subject with high $\mathrm{Pb}$ exposure ('Control $\mathrm{H}$ ') with those previously observed [4] in the hair of MMTVinfected female $\mathrm{C} 3 \mathrm{H}$ mouse exposed to $0.5 \mathrm{ppm} \mathrm{Pb}$ in the supply water ('Control $\mathrm{M}$ ') 
$\mathrm{Pb}$-exposed $\mathrm{C} 3 \mathrm{H}$ mouse with those of a $\mathrm{Pb}$ exposed woman in our control group. It may be seen that in Fig. 1, the levels of $\mathrm{Se}, \mathrm{Zn}, \mathrm{Cu}, \mathrm{Fe}$, and $\mathrm{Cr}$ in the hair of the mouse and the $\mathrm{Pb}$ unexposed woman are practically identical. However, the hair $\mathrm{Pb}$ level was significantly higher, indicating that she was also, if less, Pb-exposed.

The $0.5 \mathrm{ppm} \mathrm{Pb}$ in the water lowered the level of Se in hair to about one half of the value of the unexposed mouse, demonstrating the effect of $\mathrm{Pb}$ on hair Se. This was a low exposure, but sufficient to abolish the anticancer effect of Se. As to the other elements, the $0.5 \mathrm{ppm} \mathrm{Pb}$ in the water had little or no effect on the levels of $\mathrm{Zn}, \mathrm{Cu}$, and $\mathrm{Cr}$, but approximately doubled $\mathrm{Fe}$ and slightly lowered the $\mathrm{Zn} / \mathrm{Cu}$ ratio. In our $\mathrm{Pb}$-exposed subject, the hair Se concentration reached only one third of the value of the woman in Fig. 1. Her hair $\mathrm{Pb}$ were approximately eight times higher than the corresponding values of the unexposed human control. As $\mathrm{Pb}$ inhibits heme biosynthesis, her hair $\mathrm{Fe}$ values were increased to a similar extent. Furthermore, the exposure to $\mathrm{Pb}$ was also associated with a significant drop of the $\mathrm{Zn} / \mathrm{Cu}$ ratio, to 1.1 from 11.2 in the unexposed control (see Fig. 2). All indications thus are that her exposure to $\mathrm{Pb}$ abolished the anticancer effect of $\mathrm{Se}$ and increased her breast cancer risk.

\section{Conclusions}

Evidence is presented here that the breast cancer patients of our study were chronically exposed primarily to $\mathrm{Pb}$ and that the level of this exposure was sufficient to abolish the cancer-protecting effects of Se. Effective measures to reduce the lead burden of the population thus must become an essential part of any public health program aiming at reducing the breast cancer risk of Nigerian women.

Open Access This article is distributed under the terms of the Creative Commons Attribution Noncommercial License which permits any noncommercial use, distribution, and reproduction in any medium, provided the original author(s) and source are credited.

\section{References}

1. Ries LAG, Melbert D, Krapcho M, Mariotto A, Miller BA, Feuer EJ, Clegg L, Horner MJ, Howlader N, Eisner MP, Reichman M, Edwrds BK (eds) (2007) SEER Cancer Statistics Review, 1975-2004, National Cancer Institute. Bethesda, MD, http://seer.cancer.gov/csr/1975_2004/, based on November 2006 SEER data submission, posted to the SEER web site

2. Adebamowo CA, Ajayi OO (2000) Breast cancer in Nigeria. West Afr J Med 19:179-191

3. Schrauzer GN (2009) Selenium and selenium-antagonistic elements in nutritional cancer prevention. Crit Rev Biotechnol 29(1):10-17

4. Schraiuzer GN (2008) Effects of selenium and low doses of lead on mammary tumor development and growth in MMTV infected female mice. Biol Trace El Res 125:268-275

5. Abulude F, Ogunkoya M, Orojo T (2006) Selenium in Nigerian foods. EJPAU (Electronic Journal of Polish Agricultural Universities) 9(3), no. 06. http://www.ejpau.media.pl/volume9/issue3/art-06.html

6. Ololade IA, Adewunmi A, Ologundudu A, Adeleye A (2009) Effects of household wastes on surface and underground waters. Int J Phys Sci 4(1):22-29

7. Nduka JK, Orisakwe OE (2007) Heavy metal levels and physico-chemical quality of potable water supply in Warri, Nigeria. Ann Chim 97:867-874

8. Pfitzner MA, Thacher TD, Pettifor JM, Zoakah LJO, Fischer PR (2001) Prevalence of elevated blood lead levels in Nigerian children. Ambul Child Health 6:115-123 
9. Babalola OO, Ojo LO, Aderemi MO (2005) Lead levels in some biological samples of auto-mechanics in Abeokuta Nigeria. Indian J Biochem Biophys 42:401-403

10. Adeniyi Anetor JI (1998) Decreased immune status in Nigerian workers occupationally exposed to lead. Afr J Med Sci 27:169-172

11. Arinola OG, Charles-Davies MA (2008) Micronutrient levels in the plasma of Nigerian females with breast cancer. Afr J Biotechnol 7:1620-1623

12. FEPA (1991) Guidelines and standards for environmental pollution control in Nigeria. Federal Environmental Protection Agency (FEPA)

13. Eskin BA (1970) Iodine metabolism and breast cancer. Trans NY Acad Sci 32:911-947

14. Eskin BA et al (1995) Different tissue responses for iodine and iodide in rat thyroid and mammary glands. Biol Trace Elem Res 49:9-19

15. Eskin BA et al. (2005) Identification of breast cancer by differences in urinary iodine. Abstract Number 2150, Presentation AACR Conference

16. Doctor's Data, Inc., St. Charles, IL, 60174-2420

17. Rizk SL, Sky-Peck HH (1984) Comparison between concentrations of trace elements in normal and neoplastic human breast tissue. Cancer Res 44:5390-5394

18. Ionescu JG, Novotny J, Stejskal V, Lätsch A, Blaurock-Busch E, Eisenman-Klein M (2007) Hohe Akkumulation von Übergangsmetallen im Brustkrebsgewebe. Umw Med Ges 19:269-273

19. Ionescu JG, Novotny J, Stejskal V, Lätsch A, Blaurock-Busch E, Eisenman-Klein M (2007) Breast tumours strongly accumulate transition metals. Medica J Clin Med 2:5-9

20. Nnorom IC, Igwe JC, Ejimone JC (2005) Multielement analyses of human scalp hair samples from three distant towns in southeastern Nigeria African. J Biotechnol 4(10):1124-1127

21. Schrauzer GN (2008) Interactive effects of selenium and cadmium on mammary tumor development and growth in MMTV-infected female mice. A model study on the roles of cadmium and selenium in human breast cancer. Biol Trace Elem Res 123:27-34

22. Schrauzer GN, White DA, Schneider CJ (1977) Cancer mortality correlation studies, IV. Associations with dietary intakes of certain trace elements, notably selenium antagonists. Bioinorg Chem 7:35-56

23. Underwood EJ, Suttle NF (2000) The mineral nutrition of livestock, 3rd edn. CABI, New York, p 550

24. Bremner I (1978) Cadmium toxicity. World Rev Nutr Diet 32:165-197

25. Peter PA, Smyth PA (2003) The thyroid, iodine and breast cancer. Breast Cancer Res 5:235-238

26. Chiba M, Kamiya N, Kikuchi K (1988) Experimental study on interactions between selenium and tin in mice. Biol Trace Elem Res 15:289-301

27. Shi-P Y (1993) Effect of molybdenum supplementation on $N$-nitroso- $N$-methylurea-induced mammary carcinogenesis and molybdenum excretion in rats. Biol Trace Elem Res 39:245-256

28. Coyle YM, Hynan LS, Euhus DM, Minhajuddin AT (2005) An ecological study of the association of environmental chemicals on breast cancer incidence in Texas. Breast Cancer Res Treat 92(2):107-114

29. Schrauzer GN (2006) Interactive effects of selenium and chromium on mammary tumor development and growth in MMTV-infected female mice and their relevance to human cancer. Biol Trace Elem Res 109:281-292

30. Meacham SL, Elwell KE, Ziegler S, Carper SW (2007) Boric acid inhibits cell growth in breast and prostate cancer cell lines. In: Xu F (ed) Advances in plant and animal boron nutrition. Springer, New York, pp 299-306

31. Millikan RC, Player C, de JA René, Moorman P, Pittman G, Vannappagar V, Tse Ch-KJ, Keku T (2004) Manganese superoxide dismutase Ala-9Val polymorphism and risk of breast cancer in a population based case-control study of African Americans and whites. Breast Cancer Res 6:R264-R274

32. Mitrunen K, Sillanpää P, Kataja V, Eskelinen M, Kosma V-M, Benhamou S, Matti UM, Hirvonen A (2001) Association between manganese superoxide dismutase (MnSOD) gene polymorphism and breast cancer risk. Carcinogenesis 22:827-829

33. Welshons WV, Engler KS, Taylor JA, Grady LH, Curran EM (1995) Lithium-stimulated proliferation and alteration of phosphoinositide metabolites in MCF-7 human breast cancer cells. J Cell Physiol 165:134-144

34. Maes M, Song MC, Lin AH, Pioli R, Kenis G, Kubera M, Bosmans E (1999) In vitro immunoregulatory effects of lithium in healthy volunteers. Psychopharmacology 142:401-407

35. Schrauzer GN, Klippel KF (eds) (1991) Lithium in biology and medicine. VCH (Verlag Chemie), Weinheim

36. Pogo BGT, Holland JF (1997) Possibilities of a viral etiology for human breast cancer. A review. Biol Trace Elem Res 56:131-141 